IJOLTL, Vol. 3, No. 1, January 2018

p ISSN: 2502 2326; e -ISSN: 2502 8278

Http://ijolt1.pusatbahasa.or.id; Email: ijolt1@gmail.com

Center of Language and Culture Studies, Surakarta, Indonesia

Nurhayati, Wahyu Astuti Dwi \& Fitriana, Wilda Maylia. 2018. Effectiveness of Summarizing in Teaching Reading Comprehension for EFL Students. IJOLTL (2018), 3(1): 33 50. DOI:10.30957/ijolt1.V3i1.403.

\title{
EFFECTIVENESS OF SUMMARIZING IN TEACHING READING COMPREHENSION FOR EFL STUDENTS
}

\author{
Dwi Astuti Wahyu Nurhayati \& Maylia Wilda Fitriana \\ Institute Agama Islam Negeri Tulungagung, East Java Indonesia \\ dwiastuti507@gmail.com
}

\begin{abstract}
:
This problem highlighted in this study is the low of reading comprehension of the students at MTsN Pucanglaban Tulungagung that is caused by (1) the students' difficulties to understand about meaning in the text; (2) the students'difficulties to read and spell it correctly whether in spoken form or written form.; (3) the lack of vocabulary. The research design in this study was pre-experimental research with one group pre-test post-test design. This design involves only one group by using pre-test and post-test as the instrument. The sample was $\mathrm{VIII}^{\mathrm{A}}$ class which consists of 34 students. The result showed that the students' mean score in teaching reading comprehension before they are taught using summary technique was 84.37. While the students' mean score after they are taught using summary technique was 90.43 . By comparing significant level in t table at 0.05 , it is known that $t$ count is bigger than $t$ table. Summary technique can be used as an alternative teaching technique to teach reading comprehension to the students at JHS level.
\end{abstract}

Keywords: effectiveness, reading comprehension, summarizing.

DOI: 10.30957/ijoltl.v3i1.403.

\section{INTRODUCTION}

People conduct communication using a language or language is used to create a meaningful communication among human beings. In other words, communication is the main function of function. Communication is impossible without shared knowledge and assumptions between speakers and hearers (Stubss in Nurhayati \& Yuwartatik, 2016a). English is one of languages used as a means of communication among the speakers. In the globalization era, English plays an important role especially in international communication and in the development of education, politics, economy, and tourism. Indonesian people, in this case students use it as a means of the international communication instead of speaking mother tongue or 
IJOLTL, Vol. 3, No. 1, January 2018

p ISSN: 2502 2326; e -ISSN: 2502 8278

Http://ijolt1.pusatbahasa.or.id; Email: ijolt1@gmail.com

Center of Language and Culture Studies, Surakarta, Indonesia

Nurhayati, Wahyu Astuti Dwi \& Fitriana, Wilda Maylia. 2018. Effectiveness of Summarizing in Teaching Reading Comprehension for EFL Students. IJOLTL (2018), 3(1): 33 50. DOI:10.30957/ijolt1.V3i1.403.

language. In this case Javanese, Javanese is one of dialects which are used as first language when they communicate with their parents at informal situation, its structure is related to ethics and politeness in Javanese community in the language perspective, especially in the semiotics one (Nurhayati, 2014c; 2016b; 2016f). Indonesian is standard languages used by Indonesian people communicate among them (Nurhayati, 2016e) Using dialect is a part of speaking and it is defined as a process of using verbal and non verbal symbols in any contexts. This dialect is used to conduct communication. Meanwhile, Indonesian language is a member of the Malayo-Polynesian branch of the Austronesian language family (Nurhayati, 2016c; 2017a). English as foreign language become the third language is learnt by Indonesian students. It is considered as one of the international languages that are most widely used all over the world. In Indonesia, English is the foreign language taught at the formal schools. Furthermore, the teaching of the language starts from the kindergarten.

Today students learn English at school, they will learn the four skills namely, listening, speaking, reading and writing. All of these skills must be practiced by students and cannot be separated from one to another if one expects to be able to communicate freely in English. However, it cannot be denied that English is still a crucial problem for Indonesian students. As a matter of fact, until today most students from junior high school up to university level have difficulties in all of these skills.

Reading is form of non verbal communication. Reading enables students to understand and comprehend language through form like text passage, but some students thought that reading is perhaps the most difficult language skill to learn. However, in Indonesia the difficulties in mastering English are influenced by many factors, one of them is reading. Reading skills is important because it can help the students to find information about the general knowledge or the subject of school. Through reading the students or the people can improve their own knowledge, experience and develop new concept and broaden their horizon of thinking which are needed to ensure the continuation personal growth and adapt the changes in the world.

Teaching reading for junior high school students must be different from children in elementary school because of their different characteristics of psychological background. Peer approvals maybe considerably more important for the students than the attention of the teacher which, for younger children is so crucial. It is important for considering their classmates as the motivation in deep learning of improving teaching learning process of reading. The students must be encouraged to respond the text and situation with their own thoughts and experience, rather than 
IJOLTL, Vol. 3, No. 1, January 2018

p ISSN: 2502 2326; e ISSN: 2502 8278

Http://ijolt1.pusatbahasa.or.id; Email: ijolt1@gmail.com

Center of Language and Culture Studies, Surakarta, Indonesia

Nurhayati, Wahyu Astuti Dwi \& Fitriana, Wilda Maylia. 2018. Effectiveness of Summarizing in Teaching Reading Comprehension for EFL Students. IJOLTL (2018), 3(1): 33 50. DOI:10.30957/ijolt1.V3i1.403.

just answering question and doing abstract activities.

So far teaching English in junior high school (SMP) and senior high school (SMA) cannot be said to achieve the expected goals. One of the most obvious indicators are the constraints faced by the students in learning English. Some difficulties faced by students were studying English are as follows; the first difficulty is they have difficulties in reading English text. Many students, especially in junior high school who have a difficulty in reading the English texts. Usually, they need teacher's help to read the text word by word or sentence by sentence. The next difficulty is pronunciation. Junior high schools are the next level to learning English after elementary school. It can be reading, speaking, writing or listening. They face many difficulties, especially pronunciation in reading or speaking. Not only junior high school students face these difficulties, but also senior high school until university students. The third is lack of vocabularies that are known. It arises when the students reading the text. They will feel difficult when they are reading and understanding the text, because they don't know about the meaning of the text, how to pronounce and how to translate it manually. The language users has to know what a word sound like (its pronunciation) and what it looks like (its spelling), because some Indonesian phonemes are different form English phonemes, there are any changes of phonemes (Ramlan in Nurhayati, 2016b). These are fairly obvious characteristics and the other will be presented by the item for language user when encountering the item for the first time (Nurhayati, 2016c). Other difficulty is they also are lack of vocabularies.

In Indonesia, some English teachers still use traditional or conventional method to teach reading. Conventional method usually makes students bored because the method is monotonous and the students are passive, the interaction among them becomes dull, so it makes the learners get bored. One of the ways to make the teaching reading effective is making the student active. So they enjoy learning and they can improve their reading skill. It becomes teachers' challenging to make them more active and understand the materials which the English teachers deliver. In this case English teachers have to be creative to use any teaching strategies in teaching English skills.

Many approaches or techniques that used in teaching reading or reading comprehension, for example is using summarization technique. Summarizing teaches students how to take a large selection of text and reduce it to the main points for more concise understanding. Upon reading a passage, summarizing helps students learn to determine essential ideas and consolidate important details that support them. It is a technique that enables students to focus on key words and phrases of an assigned text that 
IJOLTL, Vol. 3, No. 1, January 2018

p ISSN: 2502 2326; e -ISSN: 2502 8278

Http://ijolt1.pusatbahasa.or.id; Email: ijolt1@gmail.com

Center of Language and Culture Studies, Surakarta, Indonesia

Nurhayati, Wahyu Astuti Dwi \& Fitriana, Wilda Maylia. 2018. Effectiveness of Summarizing in Teaching Reading Comprehension for EFL Students. IJOLTL (2018), 3(1): 33 50. DOI:10.30957/ijolt1.V3i1.403.

are worth noting and remembering. Summarizing has many advantages in reading comprehension. The students will be creative to summary the text with their own language and they will be motivated to study and read the material well. Of course, they will get many new English vocabularies. It can be effective because the summarization technique gives a positive change in the teaching learning process. It can be seen from the students' motivation.

Based on the above advantages of summarization technique, this study was conducted to know whether there is a significant different in the students' reading comprehension between before and after being taught by using summarization technique. This study investigated three points as follows: (1) How is the students' reading comprehension before being taught using summarization technique?; 2) How is the students' reading comprehension after being taught using summarization technique?; 3) Is there any significant difference between students' reading comprehension before and after using summarization technique?.

The purpose of the study are to 1) know the students' reading comprehension before being taught using summarization technique, 2) know the students' reading comprehension after being taught using summarization technique, 3) know the difference between students' reading comprehension before and after using summarization technique.

\section{REVIEW OF RELATED LITERATURE}

Reading is defined as "floats on sea of talk" (Britton, 1970). Merrit \& Culatta (1998) stated that learning depends on the use of language knowledge for the purpose of acquiring more language, concepts, and informing. The habit of reading, like other habits, develops over a period of time. Motivation and the ability to read are only two aspects of a complex series of factors contributing to the habit of reading. Why is it, educators, politicians, and parents ask, some students love to read and do so every chance they have and other students- often in the same family or classroom-dislike the whole idea of reading anything. Perhaps, because reading is an effortful activity that often involves choice, motivation is crucial to reading engagement.

Learning to read is an essential aspect of one's education, and literacy development is often compared to athletes who train for competition. The world's greatest athletes do not achieve that ability quickly or without practice. They spend hours and hours in activities to stretch, develop, and maintain muscle tone and control. Such is the nature of learning to read, which includes development in phonemic awareness and phonics and maintenance in vocabulary, fluency, and 
IJOLTL, Vol. 3, No. 1, January 2018

p ISSN: 2502 2326; e ISSN: 2502 8278

Http://ijolt1.pusatbahasa.or.id; Email: ijolt1@gmail.com

Center of Language and Culture Studies, Surakarta, Indonesia

Nurhayati, Wahyu Astuti Dwi \& Fitriana, Wilda Maylia. 2018. Effectiveness of Summarizing in Teaching Reading Comprehension for EFL Students. IJOLTL (2018), 3(1): 33 50. DOI:10.30957/ijolt1.V3i1.403.

comprehension. However, knowing how to read does not complete the whole picture of reading habit. The more students read, the better they read, and the better they read the more they read. Research published by the National Institute of Child Health and Human Development (2000), states, "The importance of reading as an avenue to improved reading has been stressed by theorists, researchers, and parishioners alike, no matter what their perspectives. There are few ideas more widely accepted than that reading is learned through reading". For various reasons, however, developing enthusiasm for reading is often as difficult for the students as is mastering the vocabulary or comprehension of the text selection. Therefore, according to Applegate \& Applegate (2004), both skill and will must be considered in the conceptualization of the ideal reader, the one with broad interests who samples widely and deeply from available sources of text and is motivated to read on regular basic. So, readers need to see both themselves as readers and have the ability to read for the habit of reading to develop and be maintained.

It can be said that just as all teachers are teachers of reading, all teachers must also encourage and model the habit of lifelong reading and learning. Most teachers are effective their students how to read, but often neglect teaching them to want to read. Armstrong, Johnson, Bridges, and Gessner (2003) state that with today's rapid technological advances, the scientific information explosion, the need for critical thinking and the scientific information explosion, the need for critical thinking and the advent of evidence-based practice, the professional" educator must promote lifelong learning. In other words one ongoing way to acquire new knowledge is to develop the habit of reading, which develops a capacity for focused attention and growth.

The training techniques were modified from the procedure developed by Brown and Palincsar (1984), which involved three concrete reading strategies training: predicting, text mapping, and summarizing. Making predictions is more than just guessing what is going on to happen next. Predicting helps students become actively involved in reading and helps to keep their interest level high. According to Duffy (2003), predicting is the strategy most relied upon as the students begin reading, so as those good readers anticipate meaning. They do this by predicting what they think is going to happen in the selection and by revising their prediction as they read. Then, text mapping is a method by which text is laid out, or mapped, to emphasize key word, phrases and concepts within documents using outlining, hyper linking and text formatting features found in most word processors. It can decrease study time, work as an 
IJOLTL, Vol. 3, No. 1, January 2018

p ISSN: 2502 2326; e ISSN: 2502 8278

Http://ijolt1.pusatbahasa.or.id; Email: ijolt1@gmail.com

Center of Language and Culture Studies, Surakarta, Indonesia

Nurhayati, Wahyu Astuti Dwi \& Fitriana, Wilda Maylia. 2018. Effectiveness of Summarizing in Teaching Reading Comprehension for EFL Students. IJOLTL (2018), 3(1): 33 50. DOI:10.30957/ijolt1.V3i1.403.

effecting teaching tool and increase reading comprehension, thereby shortening the learning curve of a subject. Carnine, Silbert and Kameenui (1997) stated that behaviors such as summarizing, paraphrasing, retelling, self-questioning, predicting and verifying, reading aloud and rereading or reading on to clarify meaning are typically referred to as metacomprehension strategies. In addition they mentioned that summarizing not only allows the students to identify the key ideas but also reduces the information in the passage to key ideas that the students can remember. Cassaza (1993) says that good readers are able to distinguish the most important ideas in a passage in a passage and summarizing them according to an appropriate organizational pattern. Furthermore she said that teaching students to summarize increase their comprehension of report text. Retelling is not simply recalling a list of events; rather, it involves selecting the most important, making personal connections, and representing the information in a logical sequence (Trehearne, 2006); whereas, summarizing requires selectively to differentiate between salient and unimportant (Dole et al, 1991). In this study only focuses on using summarization technique because of the ability of students in the elementary level. This is the reason why it is necessary to conduct the research in order to know the effectiveness of using summarization technique in reading comprehension. Any related studies also were related to this research explained below to contribute the vision of this research.

In conjunction with this vision, many studies were conducted and focused on using teaching technique and creative activities are quite effective for teaching English skills, vocabulary and other aspects. Among other were done by some researchers. The first, Shamsini \& Mousevi (2014) examined the effects of metacognitive awareness of EFL sophomore university students on the reading comprehension performance; the results indicated that the experimental groups' mean scores were a little higher than that of the control groups; however, using the one-way ANOVA, the differences observed between the means were not significant to reject the null hypothesis. Unfortunately short-term instruction of metacognitive strategies may not so effective in improving EFL learners' reading comprehension ability.

Another line of research was focused on summarization strategy, Zafarani \& Kabgani (2014) investigated the possible outcomes of the effectiveness of a main idea strategy, summarization strategy and the explicitness of the training on improving comprehension of English textual materials of Iranian ESP learners, and it found that the explicit instruction on summarizing strategy can effectively contribute to enhancing ability and aptitude of ESP learners in comprehending reading and can help them build 
IJOLTL, Vol. 3, No. 1, January 2018

p ISSN: 2502 2326; e -ISSN: 2502 8278

Http://ijolt1.pusatbahasa.or.id; Email: ijolt1@gmail.com

Center of Language and Culture Studies, Surakarta, Indonesia

Nurhayati, Wahyu Astuti Dwi \& Fitriana, Wilda Maylia. 2018. Effectiveness of Summarizing in Teaching Reading Comprehension for EFL Students. IJOLTL (2018), 3(1): 33 50. DOI:10.30957/ijolt1.V3i1.403.

up a constructive attitude toward English reading in Iranian context.

It is also supported by Nurhayati's study (2008a; 2015b; 2016d) were focused on improving students' English proficiency by creating activities and using interesting media in order to increase their motivation in learning English. It .indicates that the frequency of conducting various creative activities as teaching technique could make the students more enjoyable to study English especially reducing their burden to join activities. The students were very energetic and they needed some activities that could make them move. It implies that teachers need to be creative in creating the activities for the students, so that the students do not get bored easily. Moreover, the update research of using interesting media to inspire reading comprehension conducted by Nurhayati (2014b) also investigated retelling the ideas and summarizing text using interesting picture can increase the students 'motivation in reading class especially to improve their reading comprehension. They got more strategies to deliver their ideas to other friends after participating in creating picture series and using those reading strategies.

\section{METHOD}

In this research, the researchers use the quantitative research to achieve the purpose. The researchers used experimental research to conduct her study. Experimental research measures the effect of one manipulated and controlled (independent) variable to another (dependent) variable, like the effect of different methods of teaching to the students' achievement, the effect of an English training method to participants' English skills.

Experimental research is a research method that tests the hypothesis which has the form of cause and effect relations by manipulating defendant variable during manipulating time, the writer has to control extraneous variable, perhaps the transitional that occurred really as an effect of manipulating which is not caused by other variables. Experiments are carried out in order to explore the strength of relationship between variables. In experiment, the researcher's goal is to establish a cause and effect relationship between two phenomena. The researcher aims to establish that one variable, the independent variable, causes in another variable, that is the dependent variable.

This research is intended to investigate the effectiveness of using summarization technique in teaching reading comprehension of the second year student at MTsN Pucanglaban Tulungagung. There are two major classes of experimental designs, single-variable designs, which involve one independent variable, and factorial designs, which involve two or more independent variables. Single-variable designs are classified as pre- 
IJOLTL, Vol. 3, No. 1, January 2018

p ISSN: 2502 2326; e -ISSN: 2502 8278

Http://ijolt1.pusatbahasa.or.id; Email: ijolt1@gmail.com

Center of Language and Culture Studies, Surakarta, Indonesia

Nurhayati, Wahyu Astuti Dwi \& Fitriana, Wilda Maylia. 2018. Effectiveness of Summarizing in Teaching Reading Comprehension for EFL Students. IJOLTL (2018), 3(1): 33 50. DOI:10.30957/ijolt1.V3i1.403.

experimental, true experimental and quasi experimental (Nasution, 2006; Ary et al, 2010). This study uses Pre-experimental design. Differences attributed to application of the experimental treatment are then evaluated by comparing the pretest and post-test scores.

The effectiveness of the instructional treatment is measured by comparing the average score of the pretest and the posttest. The pretest and posttest are given to take the score of the students' reading comprehension before and after being taught by using summarization technique. Then both the scores were computed by using t-test to find out if there is significant influence of teaching English reading comprehension by using summarization technique.

Population is the object / subject that have some qualities and characteristics that are chosen to be learned and to be concluded by the researcher. The population in this study is the second year students of MTsN Pucanglaban Tulungagung in the academic year 2012/ 2013 that consists of 34 students. For the sample of this study are 34 students. The researcher selected this class because English teacher of MTsN Pucanglaban choose this class for this study.

Variable is a key term in research. Every research involves variables to be measured. When the variables are not clear, it is difficult for the researcher to conduct the research. Based on the title of the study, it has two variables; they have independent variable and dependent variable. Independent variable in this research is the use of summarization technique and dependent variable in this research is the student's achievement in reading comprehension.

The null hypothesis or Ho of this study was "There is no significant influence of using summarization technique in teaching reading comprehension of the second years of MTsN Pucanglaban Tulungagung", while the alternative hypothesis or $\mathrm{Ha}$ of this study was "There is significant influence of using summarization technique in teaching reading comprehension of the second years of MTsN Pucanglaban Tulungagung".

The primary data in this research were students' reading comprehension scores. In this study, to obtain the require scores of the students' reading comprehension, the researcher used two kinds of test. They were pre-test and post-test. Pre-test was taken before doing treatment process. This test was done to measure the students' ability in the first time. The researcher took the value to get the first information. The group got one pre-test. Pre-test was given to the students at the first meeting. The form of pre-test was to answer the question and make a summarization based on the text. The test items were 15 questions for answer question and 1 question for make a summarization. Post-test was taken after doing 
IJOLTL, Vol. 3, No. 1, January 2018

p ISSN: 2502 2326; e -ISSN: 2502 8278

Http://ijoltl.pusatbahasa.or.id; Email: ijolt1@gmail.com

Center of Language and Culture Studies, Surakarta, Indonesia

Nurhayati, Wahyu Astuti Dwi \& Fitriana, Wilda Maylia. 2018. Effectiveness of Summarizing in Teaching Reading Comprehension for EFL Students. IJOLTL (2018), 3(1): 33 50. DOI:10.30957/ijolt1.V3i1.403.

treatment process. The group got one post-test. The form of post-test was used to answer the question and make a summarization based on the text. The test items were 15 questions for answer question and 1 question to make a summary.

Quantitative data analyzes is also called as statistical analysis. It means that the result of the data served up in numerical form. Here the researcher uses t-test formula to analyze the data in order to know the students' test result which is conducted before and after using summary technique in reading comprehension. The description of t-test is as follows:

$$
t=\frac{\sum d}{\sqrt{\frac{N\left(\sum d^{2}\right)-\left(\sum d\right)^{2}}{(N-1)}}}
$$

\section{FINDINGS AND DISCUSSION}

To know the students' reading comprehension, the researchers gave pre-test and post-test in order to know their reading comprehension before and after using summarization technique. As mentioned before, the researchers used the test as the instrument in collecting data. It was given to second year of MTsN Pucanglaban Tulungagung in academic year 2012/2013 as control group and experiment group.

The number of question given by the researchers was 16 questions. To describe the data, the researchers show the score criteria of the test result, mean of test result, and percentage of the test from students.

The Students' Score before and after taught using Summarization Technique. 
IJOLTL, Vol. 3, No. 1, January 2018

p-ISSN: 2502 2326; e-ISSN: 2502 8278

Http://ijolt1.pusatbahasa.or.id; Email: ijolt1@gmail.com

Center of Language and Culture Studies, Surakarta, Indonesia

Nurhayati, Wahyu Astuti Dwi \& Fitriana, Wilda Maylia. 2018. Effectiveness of Summarizing in

Teaching Reading Comprehension for EFL Students.

IJOLTL (2018), 3(1): 33 50. DOI:10.30957/ijolt1.V3i1.403.

Table 1

List of Pre Test Scores

\begin{tabular}{|c|c|}
\hline Subject & Score \\
\hline 1 & 75 \\
\hline 1 & \\
\hline 2 & 95 \\
\hline 3 & 80 \\
\hline 4 & 75 \\
\hline 5 & 82 \\
\hline 6 & 80 \\
\hline 7 & 92 \\
\hline 8 & 80 \\
\hline 9 & 85 \\
\hline 10 & 82 \\
\hline 11 & 90 \\
\hline 12 & 95 \\
\hline 13 & 72 \\
\hline 14 & 80 \\
\hline 15 & 88 \\
\hline 16 & 76 \\
\hline 17 & 95 \\
\hline 18 & 88 \\
\hline 19 & 75 \\
\hline 20 & 95 \\
\hline 21 & 85 \\
\hline 22 & 75 \\
\hline 23 & 88 \\
\hline 24 & 90 \\
\hline 25 & 75 \\
\hline 26 & 87 \\
\hline 27 & 84 \\
\hline 28 & 92 \\
\hline 29 & 95 \\
\hline 30 & 80 \\
\hline \multicolumn{2}{|c|}{ Total Score } \\
\hline
\end{tabular}

Table 2

List of Post Test Scores

\begin{tabular}{|c|c|}
\hline Subject & Score \\
\hline 1 & 84 \\
\hline 1 & \\
\hline 2 & 88 \\
\hline 3 & 85 \\
\hline 4 & 88 \\
\hline 5 & 92 \\
\hline 6 & 85 \\
\hline 7 & 92 \\
\hline 8 & 92 \\
\hline 9 & 90 \\
\hline 10 & 88 \\
\hline 11 & 92 \\
\hline 12 & 88 \\
\hline 13 & 90 \\
\hline 14 & 92 \\
\hline 15 & 95 \\
\hline 16 & 90 \\
\hline 17 & 92 \\
\hline 18 & 90 \\
\hline 19 & 84 \\
\hline 20 & 96 \\
\hline 21 & 92 \\
\hline 22 & 88 \\
\hline 23 & 95 \\
\hline 24 & 92 \\
\hline 25 & 96 \\
\hline 26 & 88 \\
\hline 27 & 90 \\
\hline 28 & 95 \\
\hline 29 & 92 \\
\hline 30 & 92 \\
\hline Total Score & 2713 \\
\hline
\end{tabular}


IJOLTL, Vol. 3, No. 1, January 2018

p-ISSN: 2502 2326; e-ISSN: 2502 8278

Http://ijolt1.pusatbahasa.or.id; Email: ijolt1@gmail.com

Center of Language and Culture Studies, Surakarta, Indonesia

Nurhayati, Wahyu Astuti Dwi \& Fitriana, Wilda Maylia. 2018. Effectiveness of Summarizing in Teaching Reading Comprehension for EFL Students.

IJOLTL (2018), 3(1): 33 50. DOI:10.30957/ijoltl.V3i1.403.

Table 3

The Computation Table of t-test Scores of Using Summarization Technique in Teaching Reading Comprehension

\begin{tabular}{|c|c|c|c|c|}
\hline No & $\mathrm{X}_{1}$ & $\mathrm{X}_{2}$ & $\mathrm{D}$ & $\mathrm{d}^{2}$ \\
\hline 1 & 75 & 84 & 9 & 81 \\
\hline 2 & 95 & 88 & $\overline{7}$ & 49 \\
\hline 3 & 80 & 85 & 5 & 25 \\
\hline 4 & 75 & 88 & $\begin{array}{l}1 \\
3\end{array}$ & $\begin{array}{l}16 \\
9\end{array}$ \\
\hline 5 & 82 & 92 & $\begin{array}{l}1 \\
0\end{array}$ & $\begin{array}{l}10 \\
0\end{array}$ \\
\hline 6 & 80 & 85 & 5 & 25 \\
\hline 7 & 92 & 92 & 0 & 0 \\
\hline 8 & 80 & 92 & $\begin{array}{l}1 \\
2\end{array}$ & $\begin{array}{l}14 \\
4\end{array}$ \\
\hline 9 & 85 & 90 & 5 & 25 \\
\hline 10 & 82 & 88 & 6 & 36 \\
\hline 11 & 90 & 92 & 2 & 4 \\
\hline 12 & 95 & 88 & $\overline{7}$ & 49 \\
\hline 13 & 72 & 90 & $\begin{array}{l}1 \\
8\end{array}$ & $\begin{array}{l}32 \\
4\end{array}$ \\
\hline 14 & 80 & 92 & $\begin{array}{l}1 \\
2\end{array}$ & $\begin{array}{l}14 \\
4\end{array}$ \\
\hline 15 & 88 & 95 & 7 & 49 \\
\hline 16 & 76 & 90 & $\begin{array}{l}1 \\
4\end{array}$ & $\begin{array}{l}19 \\
6\end{array}$ \\
\hline 17 & 95 & 92 & $\overline{3}$ & 9 \\
\hline 18 & 88 & 90 & 1 & 1 \\
\hline 19 & 75 & 84 & 9 & 81 \\
\hline 20 & 95 & 96 & 1 & 1 \\
\hline 21 & 85 & 92 & 7 & 49 \\
\hline 22 & 75 & 88 & $\begin{array}{l}1 \\
3\end{array}$ & $\begin{array}{l}16 \\
9\end{array}$ \\
\hline 23 & 88 & 95 & 7 & 49 \\
\hline 24 & 90 & 92 & 2 & 4 \\
\hline 25 & 75 & 96 & 2 & 44 \\
\hline
\end{tabular}


IJOLTL, Vol. 3, No. 1, January 2018

p-ISSN: 2502 2326; e-ISSN: 2502 8278

Http://ijolt1.pusatbahasa.or.id; Email: ijolt1@gmail.com

Center of Language and Culture Studies, Surakarta, Indonesia

Nurhayati, Wahyu Astuti Dwi \& Fitriana, Wilda Maylia. 2018. Effectiveness of Summarizing in Teaching Reading Comprehension for EFL Students. IJOLTL (2018), 3(1): 33 50. DOI:10.30957/ijoltl.V3i1.403.

\begin{tabular}{|l|l|l|l|l|}
\hline & & & 1 & 1 \\
\hline 26 & 87 & 88 & 1 & 1 \\
\hline 27 & 84 & 90 & 6 & 36 \\
\hline 28 & 92 & 95 & 3 & 9 \\
\hline \multirow{2}{*}{29} & 95 & 92 & - & 9 \\
& & & 3 & \\
\hline \multirow{2}{*}{30} & 80 & 92 & 1 & 14 \\
& & & 2 & 4 \\
\hline \multirow{2}{*}{ To } & 25 & 27 & 8 & 24 \\
tal & 31 & 13 & 5 & \\
\hline
\end{tabular}

Where:

$\mathrm{X}_{1}=$ Pre test score of the students

$\mathrm{X}_{2}=$ Post test score of the students

$\mathrm{d}=\mathrm{X}_{2}-\mathrm{X}_{1}$

$\mathrm{d}^{2}=\left(\mathrm{X}_{2}-\mathrm{X}_{1}\right)^{2}$

The computation of $\mathrm{T}$ test

$$
t=\frac{\sum d}{\sqrt{\frac{N\left(\sum d^{2}\right)-\left(\sum d\right)^{2}}{(N-1)}}}
$$


IJOLTL, Vol. 3, No. 1, January 2018

p ISSN: 2502 2326; e $\sim$ ISSN: 2502 8278

Http://ijolt1.pusatbahasa.or.id; Email: ijolt1@gmail.com

Center of Language and Culture Studies, Surakarta, Indonesia

Nurhayati, Wahyu Astuti Dwi \& Fitriana, Wilda Maylia. 2018. Effectiveness of Summarizing in Teaching Reading Comprehension for EFL Students. IJOLTL (2018), 3(1): 33 50. DOI:10.30957/ijoltl.V3i1.403.

$$
\begin{aligned}
& =\frac{185}{\sqrt{\frac{30(2423)-(185)^{2}}{(30-1)}}} \\
& =\frac{185}{\sqrt{\frac{72690-34225}{29}}} \\
& =\frac{185}{\sqrt{\frac{38465}{29}}} \\
& =\frac{185}{\sqrt{1326,4}} \\
& =\frac{185}{36.4}=5.08
\end{aligned}
$$

That is the computation of $\mathrm{T}$ test formula of the pre-test score and post test score. The result of data analysis (t-test) was 5,08 and the value of t-table at level of significance $5 \%$ and the degrees of freedom 29 was 1,699 (Butler:1985:172). It means that the result of t-test was higher that t-table. Therefore, Ho (null hypothesis) was rejected. These finding mean that summarization technique gives the significant effect to the second year students' reading comprehension. Thus, teaching reading comprehension by summarization technique was effective to build the student's reading comprehension. It is in line with Mistar, Zuhairi \& Yanti's research who posit that the students 'ability of grasping literal and inferential comprehension from given passages was significantly enhanced through trainings in the use of reading strategies, including predicting, text mapping, and summarizing.

\section{DISCUSSION}

Based on research finding, it showed that the mean scores seem significant different between pre-test that using traditional or no method and post-test that using summarization technique. The mean score of students before they are taught using summarization technique is 84.37. While, the mean score of students after they are taught using summarization technique is 90.43. It means that the post test score was higher than the pre test score. After computating with t-test, we get the result. It is 5.08. Of course, it must be 
IJOLTL, Vol. 3, No. 1, January 2018

p ISSN: 2502 2326; e ISSN: 2502 8278

Http://ijolt1.pusatbahasa.or.id; Email: ijolt1@gmail.com

Center of Language and Culture Studies, Surakarta, Indonesia

Nurhayati, Wahyu Astuti Dwi \& Fitriana, Wilda Maylia. 2018. Effectiveness of

Summarizing in Teaching Reading Comprehension for EFL Students. IJOLTL (2018), 3(1): 33 50. DOI:10.30957/ijolt1.V3i1.403.

compared t-test result with t-table. The value of t-table at level of significance $5 \%$ and the degrees of freedom 29 was 1,699. It means that the t-test result was higher than t-table. For the result, there is significant influence of using summarization technique in teaching reading comprehension of the second years of MTsN Pucanglaban Tulungagung. It means that the $\mathrm{Ha}$ is accepted and Ho is rejected, because the t-test result was higher than t-table.

It can be said that summarization technique gives significant effect to the students' reading comprehension. It was effective to the students' reading comprehension. It also makes better the student's attitude and interest in using of summarization technique. In general, it could be stated that summarization technique had a positive effect on the students' reading comprehension. The students were more interested in reading and they also feel enjoyable to read the text. Summarization technique also could motivate the students in learning activities. It is parallel with Bean \& Steenwyk in Carnie et al (1990) who reported their research on the sixth-grade students. They compared two groups of students; one group got an explicit instruction of how to summarize, while the other group got an advice of how to make summaries. After a certain period of treatment, the two groups were tested and compared. The comparison showed that the students who got explicit instruction of how to summarize outperformed those who did not in both summary writing and reading comprehension. This is also in line with what Flood \& Lapp (1990) reported a similar finding when they refer to Salisbury's research on the effectiveness of summarizing training found that the students who were made aware of the important points in the passage and asked to summarize those points had significantly increased their reading comprehension scores. On this point, McNamara (2007) concludes that strategy instruction of reading is particularly needed and effective for those students who are struggling most, namely those with less domain knowledge or lower reading skills.

The implication of the finding of the present research toward the teaching reading comprehension is that reading strategies, such as predicting, text mapping and summarizing, are worth applying even for student of English as a foreign language with an elementary level of proficiency. Thus English teachers should be encouraged to apply these reading strategies in their reading comprehension classes. Grabe (2009) suggests that reading teachers should incorporate strategy instruction as a part of everyday reading instruction and work toward the automatization of strategy use for fluent reading. In this case, Hudson (2011) provides guidelines to make reading strategy instruction effective. Those are as follows: (1) the concept and the objective of strategy use should be carefully explained, (2) the use of strategies in reading should be properly modeled, (3) sufficient practice and feedback should be provided, (4) transfer of the trained skills to new reading tasks should be encouraged, and 5) 
IJOLTL, Vol. 3, No. 1, January 2018

p ISSN: 2502 2326; e -ISSN: 2502 8278

Http://ijolt1.pusatbahasa.or.id; Email: ijolt1@gmail.com

Center of Language and Culture Studies, Surakarta, Indonesia

Nurhayati, Wahyu Astuti Dwi \& Fitriana, Wilda Maylia. 2018. Effectiveness of

Summarizing in Teaching Reading Comprehension for EFL Students. IJOLTL (2018), 3(1): 33 50. DOI:10.30957/ijoltl.V3i1.403.

content-based materials should be embedded in instructional activities to provide more authentic purposes of reading comprehension.

\section{CONCLUSION AND SUGGESTION}

Based on the research finding it can be concluded that there is significant influence of using summarization technique of reading comprehension on students of the second years of MTsN Pucanglaban Tulungagung. It also means that there is different score to the students before they are taught using summarization technique and the students after they are taught using summarization technique. This conclusion is gotten by analyzing the result of statistical test and using $\mathrm{t}$ test shows that the $\mathrm{t}$ count is bigger than $\mathrm{t}$ table at the significant level 0,05 and $\mathrm{df} 29$. The result of $t$ test is 5.08 while the $t$ table shows 1.699. It can be inferred that the summarization technique is effective to conduct teaching reading comprehension.

From the research, the researchers recommended some suggestions whether there is any significant effect using summarization technique in teaching reading comprehension of the second year. For the English teacher, especially in junior high school, the summarization technique is effective to teach reading comprehension. It is suggested to the English teacher to use summarization technique in order to make the students easier understand the reading text, especially understand about the main idea and they can summary the text well. For the students, The researcher recommended to use summarization technique when they are learning about reading comprehension text, because it was proved that by using summarization technique, the students could understand about the text more easily. Not only for reading, summarization also bring benefit for their vocabulary mastery, but also it could make the students practice to re-telling or rewrite what they read. Finally, for future researcher, It is hoped that this research could be conduct as a reference to other research in the similar area or others.

\section{REFERENCES}

Applegate, A.J., \& Applegate, M.D. (2004). The Peter Effect: Reading Habits and Attitudes of Preservice Teachers. The Reading Teacher. 57(6), 555-563.

Amstrong, M.L, Johnston, B.A., Bridges, R.A., \& Gessner, B.A. 2003. The Importance of Graduate Education on Reading Reading for Lifelong Learning.Journal of Continuing Education in Nursing, 43(1), 19-25.

Ary, D., Jacobs, C.L., Sorensen, C., Razavieh, A. (2010). Introduction to Research in Education ( $\left.8^{\text {th }} E d\right)$. USA: Wadsworth, Cengage Learning.

Briton, J. (1970). Langugae and Learning. Coral Gables, Florida: University of Miami Press. 
IJOLTL, Vol. 3, No. 1, January 2018

p ISSN: 2502 2326; e $\sim$ ISSN: 2502 8278

Http://ijoltl.pusatbahasa.or.id; Email: ijolt1@gmail.com

Center of Language and Culture Studies, Surakarta, Indonesia

Nurhayati, Wahyu Astuti Dwi \& Fitriana, Wilda Maylia. 2018. Effectiveness of

Summarizing in Teaching Reading Comprehension for EFL Students. IJOLTL (2018), 3(1): 33 50. DOI:10.30957/ijolt1.V3i1.403.

Brown, A., \& Palinscar,A. (1984). Reciprocal teaching of comprehensionfostering and comprehension monitoring activities. Cognition and Instruction, Vo. 1 (2), 117 175.http://dx.doi.org/10.1207/s1532690xci0102_1.

Butler, C. (1985). Statistics in Linguistics. Great Britain by Billings Ltd, Worcester.

Carnine, D., Silbert,J. \& Kameenui, E,J. (1990). Direct instruction reading. Ohio: Merril Publishing Company.

Cassaza,M.E. (1993). Using a model of direct instruction to teach summary writing in a college reading class. Journal of Reading, Vol.3 (3), 202208.

Dole, J.A., Duffy,G.G., Roehler,L.R., \& Pearson, P.D. (1991). Moving from the old to the new: Research on Reading Comprehension Instruction. Review of Educational Research, 61,239-264.

Duffy, G. (2003). Explaining reading: A resource for teaching concepts, skills and strategies. New York: Guilford Press.

Floop, J. \& Lapp, D. (1990). Reading comprehension instruction for at-risk students: Research-based instruction that can make a difference. Journal of Reading, 33 (7), 490-496.

Grabe, W. (2009). Reading in second language: Moving from theory to practice. Cambridge: Cambridge University Press.

Hudson, T. (2011). Teaching second language reading. Oxford: Oxford University Press.

McNamara, D.S. (Ed). (2007). Reading comprehension strategies: Theory, interventions, and technologies. Mahwah,NJ: Erlbaum.

Merrit, D., \& Culatta,B. (1998). Language Intervention in the Classroom. Toronto: Nelson Thomas Learning.

Mistar,J. Zuhairi, A., \&Yanti, N. (2016). Strategies training in the teaching of reading comprehension foe EFL learners in Indonesia. English Language Teaching, Vol. 9 (2), 49-56.

National Institute of Child Health and Human Development. (2000). Report of the National Reading Panel. Teaching Children to read: An evidence-based assessment of the Scientific Research Literature an Reading and its implications for Reading Instruction. Washington, 
IJOLTL, Vol. 3, No. 1, January 2018

p ISSN: 2502 2326; e $\sim$ ISSN: 2502 8278

Http://ijoltl.pusatbahasa.or.id; Email: ijolt1@gmail.com

Center of Language and Culture Studies, Surakarta, Indonesia

Nurhayati, Wahyu Astuti Dwi \& Fitriana, Wilda Maylia. 2018. Effectiveness of

Summarizing in Teaching Reading Comprehension for EFL Students. IJOLTL (2018), 3(1): 33 50. DOI:10.30957/ijoltl.V3i1.403.

DC: U.S. Government Printing Office.

Nasution, S. (2006). Metode Research: Penelitian Ilmiah. Cetakan ke delapan. Jakarta: Bumi Aksara.

Nurhayati, D. A.W (2008a). Improving Students 'English Vocabulary Mastery through Games (A Classroom Action Research in the Islam Kindergarten of Al-Irsyad Madiun in the Academic Year 2007/2008). Surakarta.Graduate School of Sebelas Maret University.

Nurhayati, D.A.W. (2014b). Using Picture Series to Inspire Reading Comprehension for the Second Semester Students of English Department of IAIN Tulungagung. Dinamika Ilmu Journal. Vol.14.No.2.Desember 2014, 176-189.

Nurhayati, D.A.W. (2014c). Kesantunan pragmatik dalam bahasa guru bahasa Inggris di sekolah dasar Islam in proceedings of the $1^{\text {st }}$ PRASASTI (Pragmatik: Sastra dan Linguistik, 1, 27 November, 52-60.

Nurhayati, D.A.W. (2015a). Morphological process and morphophonemic process of Alay Variation. Lingua. Vol. 14 (2), 176-189.

Nurhayati, D.A.W. (2015b). Improving students'English pronunciation ability through go fish game and maze game. Dinamika Ilmu Journal, Vol. 15 (2), 215-233.

Nurhayati, D. A. W., \&Yuwartatik. (2016a). Illocutionary and perlocutionary acts on main characters dialogues in John Milne's Novel: 'The Black Cat. IJOLTL, Vol. 1 (1), 67-96.

Nurhayati, D. A. W. (2016b). Word formation processes and a technique in understanding Waria slang Tulungagung. EFL Journal. Vol. 1(1), 5987.

Nurhayati, D.A.W. (2016c). Phonological System of Tengger dialect in ngoko speech level. Indonesian Journal of EFL and Linguistics, Vol. 1 (1),112.

Nurhayati, D.A.W. (2016d). Using local drama in writing and speaking: EFL learners' creative expression. Journal of English Language Teaching and Linguistics, Vo. 1 (1),55-77.

Nurhayati, D A.W, Djtamika, Riyadi,S. Wiratno, T. (2016e). Indonesian influence in developing speaking skill in learning English: EFL learners impediments. Proceedings of the third International Seminar PRASASTI,(III, 2-3 August 2016).6796.http://dx.doi.org/10.20961/pras.v0i0.

Nurhayati, D.A.W. (2016f). Investigating morphological process of payandra on Javanese metaphor. Journal of English Language Teaching and Linguistics (JELTL), Vol.1 (3), 245-259. 
IJOLTL, Vol. 3, No. 1, January 2018

p-ISSN: 2502 2326; e-ISSN: 2502 8278

Http://ijolt1.pusatbahasa.or.id; Email: ijolt1@gmail.com

Center of Language and Culture Studies, Surakarta, Indonesia

Nurhayati, Wahyu Astuti Dwi \& Fitriana, Wilda Maylia. 2018. Effectiveness of Summarizing in Teaching Reading Comprehension for EFL Students. IJOLTL (2018), 3(1): 33 50. DOI:10.30957/ijolt1.V3i1.403.

Nurhayati D A.W, Djatmika, Riyadi, S. Wiratno, T. (2017a). Effect of Students' Term and Educational Institution on the Arising of Indonesian Morphology-Syntactical Interference in ELLT. Dinamika Ilmu Journal, Vol. 17 (1), 101-114.

Shamsini, S. \& Mousavi, A.S. (2014). Metacognitive strategy awareness and its effect on the learners'reading comprehension ability: Revisited. International Journal of English and Education, Vol.3 (3), July 2014, 40-56.

Trehearne, M.P. (Ed.). (2006). Comprehensive Literarcy Resource for Grardes 3-6 teachers. Vernon Hills: ETA/Cuisanire.

Zafarani,P \& Kabgani,S. (2014). Summarization strategy training and reading comprehension of Iranian ESP learners, Procedia-Social and Behavior Sciences, Vol.98,1959-1965. 